\title{
New thermostable D-methionine amidase from Brevibacillus borstelensis BCS-1 and its application for D-phenylalanine production
}

\author{
Dae Heoun Baek ${ }^{a}$, Jae Jun Song ${ }^{a}$, Seung-Goo Lee ${ }^{\text {a }}$, Seok Joon Kwon ${ }^{\text {a }}$, \\ Yasuhisa Asano ${ }^{c}$, Moon-Hee Sung ${ }^{a}, b, *$ \\ ${ }^{a}$ Biocatalysis Research Laboratory (National Research Laboratory), Korea Research Institute of Bioscience and Biotechnology (KRIBB), \\ 52 Oun-dong, Yuseong, Daejeon 305-333, South Korea \\ ${ }^{\mathrm{b}}$ Bioleaders Corporation, Yuseong, Daejeon 305-600, South Korea \\ ${ }^{\mathrm{c}}$ Biotechnology Research Center, Toyama Prefectural University, Toyama, Japan
}

Received 28 May 2002; received in revised form 24 September 2002; accepted 30 September 2002

\begin{abstract}
A new thermostable D-methionine amidase was found in a cell-free extract of Brevibacillus borstelensis BCS-1. After five steps of purification, the specific activity increased approximately 207 -fold and the purity was more than $98 \%$. The molecular weight of the enzyme was estimated to be $199 \mathrm{kDa}$ by gel permeation chromatography and $30 \mathrm{kDa}$ by sodium dodecyl sulfate-polyacrylamide gel electrophoresis, which indicates that the thermostable D-methionine amidase was a homo-hexamer consisting of a single subunit. The purified enzyme was stable up to $65^{\circ} \mathrm{C}$ within a broad $\mathrm{pH}$ range from 6.5 to 10.0 , and its maximum activity was measured at $\mathrm{pH} 9.5$ and $70{ }^{\circ} \mathrm{C}$. The enzyme activity increased about five-fold with the addition of $\mathrm{Co}^{2+}$, yet was strongly inhibited by $\mathrm{Hg}^{2+}, 2$-mercaptoethanol, dithiothreitol, and ethylenediaminetetracetic acid.

The thermostable D-methionine amidase exhibited a high amidase activity and D-stereospecificity toward D-amino acid amides and esters, yet did not hydrolyze D-peptides. The catalytic efficiencies $\left(k_{\mathrm{cat}} / K_{\mathrm{m}}, \mathrm{mM}^{-1} \mathrm{~s}^{-1}\right)$ of the enzyme for D-methioninamide and D-alaninamide were 3086 and 21.5, respectively, and the enantiomeric excess (ee) and enantiomeric ratio of D-phenylalanine produced from DL-phenylalaninamide were 97.1 and $196 \%$, respectively.
\end{abstract}

(C) 2002 Elsevier Science Inc. All rights reserved.

Keywords: Thermostable D-methionine amidase; Thermophilic bacterium; Brevibacillus borstelensis BCS-1; D-Phenylalanine production

\section{Introduction}

D-Amino acid-containing synthetic and natural peptides exhibit greater antimicrobial properties than peptides containing the corresponding L-isomers, because D-isomers would seem to be more stable than L-isomers against proteolytic digestion [11]. Accordingly, D-amino acids are being increasingly utilized as intermediates for the production of pharmaceuticals, food additives, and agrochemicals [30]. Among these amino acids, D-phenylglycine, D-cystein, and D-aspartic acid are used for the synthesis of beta-lactam antibiotics, insecticides, and synthetic sweeteners, respectively [4,10,12,13,22-24].

To synthesize D-amino acids, many useful methods, such as chemical, fermentative, and enzymatic production, have already been developed $[21,30]$. In chemical synthesis methods, D-amino acids are produced by the chiral resolution of

* Corresponding author. Tel.: +82-42-860-4372; fax: +82-42-860-4595.

E-mail address: smoonhee@mail.kribb.re.kr (M.-H. Sung).
DL-amino acids; however, these systems have a low yield and high cost as regards the large-scale production of D-amino acids [30]. Fermentation methods are used to manufacture most L-amino acids, yet this type of method has hardly been applied to produce D-amino acids, as it is difficult to achieve a high optical purity and productivity. In contrast, enzymatic biotransformations, which produce optically pure D-amino acids from DL-racemic mixtures without any by-products from D-amino acid-specific enzymes, would appear to be the most feasible method for the production of D-amino acids with regard to high optical purity and productivity [21].

The stability of the biocatalyst is the most important factor determining the productivity in an enzymatic process. Generally, thermophilic bacteria produce thermostable enzymes with a high stability as regards heat, organic solvents, $\mathrm{pH}$, and chemical denaturants.

As such, the synthesis of biologically active peptides incorporating D-amino acids instead of their L-counterparts could lead to metabolically stable and long acting products. For this reason, serious attention has been paid to D-amino 
acid amidase as a potential catalyst for the production of optically pure D-amino acids from DL-amino acid amides.

D-Amino acid-specific enzymes have already been reported from a variety of microbial sources $[1,2,7,28,29]$. Among these enzymes, D-stereospecific amino acid amidase [2] is known to catalyze the hydrolysis of D-amino acid amides to yield D-amino acid and ammonia. The origin of this enzyme was a mesophile, however, so far there have been no reports on a thermostable D-stereospecific amino acid amidase from a thermophile. Accordingly, the current study attempted to isolate a thermostable D-stereospecific amino acid amidase from a thermophile to produce optically pure D-amino acids from DL-amino acid amides under high temperature conditions.

Previously, the current authors reported on the production of a D-stereospecific dipeptidase from the thermophile Bacillus sp. BCS-1 [3]. In addition to this enzyme, the microorganism also exhibits a high thermostable D-methionine amidase activity after the late-log phase in a liquid culture medium.

Consequently, the current paper reports on the purification and characterization of a new thermostable D-methionine amidase from Brevibacillus borstelensis BCS-1, along with a speculation on the $\mathrm{NH}_{2}$-terminal amino acid sequence of the purified thermostable D-methionine amidase.

\section{Materials and methods}

\subsection{Chemicals}

The D-amino acid amides, L-amino acid amides, and esters were all purchased from Bachem (Bubendorf, Switzerland). The D-dipeptides and oligopeptides were purchased from Sigma (St. Louis, MO) and the aliphatic amides from Wako Pure Chemicals (Japan). The synthesized D-amino acid amides were obtained from Prof. Yasuhisa Asano (Toyama Prefectural University, Japan). The D-amino acid oxidase (DAAO), L-amino acid oxidase (LAAO), 4-amino antipyrine (4AP), $N$-ethyl- $N$-(2-hydroxy-3-sulfopropyl)- $m$ toluidine (TOOS), $o$-phthaldialdehyde (OPA), and $N$-acetylL-cysteine (NAC) were all purchased from Sigma (St. Louis, $\mathrm{MO})$.

\subsection{Microorganism and culture conditions}

The culture medium for the production of the enzyme was a Luria-Bertani broth (LB) medium. For preservation, the strain was kept for several months at $-70^{\circ} \mathrm{C}$ in a deep freezer and subcultures were prepared by incubating the organisms for $16 \mathrm{~h}$ at $55^{\circ} \mathrm{C}$ in $10 \mathrm{ml}$ test tubes containing the LB medium. The resulting subcultures were inoculated into $100 \mathrm{ml}$ volumes of the same medium and cultivated using a rotary shaking incubator $(200 \mathrm{rpm})$ for $10 \mathrm{~h}$ at the same temperature. Finally, these cultures were used to inoculate a 30-1 fermentor (Korea Fermentation Co. Ltd, South Korea) and the preparation was incubated for $25 \mathrm{~h}$ at $55^{\circ} \mathrm{C}$ with agitation (200 rpm) and aeration (from 110 to $387 \mathrm{~g} / \mathrm{cm}^{2}$ ). The $\mathrm{pH}$ of the culture medium was maintained at $\mathrm{pH}$ 7.2. The cells were harvested after the stationary phase by centrifugation for $20 \mathrm{~min}$ at $14,000 \times g$ at $4{ }^{\circ} \mathrm{C}$ and washed twice with $0.85 \% \mathrm{NaCl}$ solution. The yield was $7.5 \mathrm{~g}$ (wet weight) of cells per liter.

\subsection{Analysis of $16 \mathrm{~S}$ rRNA gene}

The 16S rRNA gene of strain BCS-1 was amplified by a polymerase chain reaction (PCR) with the forward primer $5^{\prime}$ AGAGTTTGATCCTGGCTCAG- $3^{\prime}$ and reverse primer $5^{\prime}$ AGAAAGGAGGTGATCCAGCC-3', which correspond to nucleotides 8-27 and 1525-1544 of the Escherichia coli 16S rRNA gene sequence, respectively [31]. The amplified PCR product was cloned in pT7Blue (Novagen, Germany), and both strands were sequenced using the dideoxy-chain termination method. The 16S rRNA gene sequence and a representative group of Bacillus sequences were obtained from the GenBank, DDBJ, and EMBL database.

\subsection{Purification of $\mathrm{D}-$ methionine amidase}

The cells $(300 \mathrm{~g}$, wet weight) were suspended in 21 of $0.1 \mathrm{M}$ Tris- $\mathrm{HCl}$ buffer ( $\mathrm{pH} 8.0$ ) containing $0.3 \mathrm{mM}$ phenylmethanesulphonyl fluoride (PMSF) as a protease inhibitor and disrupted with a Dyno-mill type KDL (Willy A. Bachofen AG, Maschinenfabrik, Basel, Switzerland) using 0.1 -mm diameter glass beads at $4{ }^{\circ} \mathrm{C}$. The suspension was centrifuged to remove any unbroken cells and debris. The extract was then further centrifuged $(150,000 \times g, 90 \mathrm{~min})$ to remove all membrane-associated material, thereby generating a soluble extract. This extract was used to detect the D-methionine amidase activity and then as the starting material for the purification of the enzyme.

Ammonium sulfate fractionation was performed and the active fractions precipitated at concentration values between 50 and $80 \%$. The protein pellet was suspended and dialyzed against $0.1 \mathrm{M}$ Tris- $\mathrm{HCl}$ buffer (pH 8.0) containing $0.3 \mathrm{mM}$ PMSF. This solution $(200 \mathrm{ml})$ was loaded onto a Resource Q column (Pharmacia, Sweden) that had been pre-equilibrated with the same buffer. The proteins were eluted using a linear gradient of $\mathrm{NaCl}$ from 0 to $0.5 \mathrm{M}$. The active fractions $(150 \mathrm{ml})$ were then pooled, concentrated, and loaded onto a Phenyl Superose column (Pharmacia, Sweden) that had been equilibrated with $0.1 \mathrm{M}$ Tris- $\mathrm{HCl}$ buffer ( $\mathrm{pH}$ 8.0) containing $0.3 \mathrm{mM}$ PMSF and $0.5 \mathrm{M}$ ammonium sulfate. The enzyme was eluted using a linear descending gradient of ammonium sulfate from 0.5 to $0 \mathrm{M}$. The active fractions $(5 \mathrm{ml})$ were dialyzed and loaded onto a Mono Q HR 5/5 column (Pharmacia, Sweden). The proteins were eluted using a linear gradient of $\mathrm{NaCl}$ and the active fractions dialyzed against $0.1 \mathrm{M}$ Tris- $\mathrm{HCl}$ buffer (pH 8.0) containing $0.3 \mathrm{mM}$ PMSF. The dialyzed enzyme solution $(2 \mathrm{ml})$ was then loaded onto a Mono S column (Pharmacia, Sweden) and the active 
fractions eluted using a linear gradient of $\mathrm{NaCl}$ and concentrated using an Amicon PM-10 ultrafiltration membrane (USA).

\subsection{Enzyme assay for D-methionine amidase}

The enzyme activity was assayed at $55^{\circ} \mathrm{C}$ based on measuring the production of $\mathrm{D}$-amino acids from the $\mathrm{D}$-amino acid amides. The assay mixture $(0.5 \mathrm{ml})$ contained $0.1 \mathrm{M}$ Tris-HCl (pH 8.0), 5.0 mM D-amino acid amides, and the enzyme solution. The reaction was carried out at $55^{\circ} \mathrm{C}$ and terminated after $30 \mathrm{~min}$ by boiling for $5 \mathrm{~min}$. The hydrogen peroxide liberated from the D-amino acids by the action of DAAO was determined by the oxidative coupling with 4AP and TOOS in the presence of peroxidase. The standard reaction mixture $(1.5 \mathrm{ml})$ contained $0.1 \mathrm{M}$ Tris- $\mathrm{HCl}(\mathrm{pH} 8.0)$, 0.72 units of DAAO, $11 \mathrm{mM}$ TOOS, $0.53 \mathrm{mM} 4 \mathrm{AP}$, and 68 units of peroxidase and was incubated with shaking at $30^{\circ} \mathrm{C}$ for $60 \mathrm{~min}$, unless otherwise specified. The formation of quinone-imine dye was measured at $555 \mathrm{~nm}$ and quantified based on the standard curve of D-amino acid.

The L-amino acid amidase activity toward the L-amino acid amides was reciprocally assayed with L-amino acid oxidase (LAAO) under the same conditions. The enzyme activities on the chromogenic compounds, such as D-amino acid- $p$-nitroanilides, were measured using a spectrophotometer at $405 \mathrm{~nm}$ to determine the amount of $p$-nitroaniline.

For a quantitative determination of the hydrolysis of the DL-amino acid amides, a reaction mixture $(0.2 \mathrm{ml})$ containing $0.1 \mathrm{M}$ Tris- $\mathrm{HCl}(\mathrm{pH} 8.0), 5.0 \mathrm{mM}$ DL-amino acid amides, and $20 \mu \mathrm{l}$ of the enzyme solution was used. The reaction was stopped by boiling for $5 \mathrm{~min}$, and then the denatured proteins were removed by centrifugation. The reactant was analyzed using $50 \mathrm{mM}$ sodium acetate buffer ( $\mathrm{pH}$ 6.8): $\mathrm{MeOH}$ linear gradient HPLC system after being derivatized with OPA and NAC [32]. The derivatized amino acids were separated by reversed-phase HPLC on a Rexchrome S5-100-ODS $(4.6 \mathrm{~mm} \times 25 \mathrm{~cm}, 5 \mu \mathrm{m}$, Regis Chem. Co., USA) and monitored using a fluorescence detector (excitation at $342 \mathrm{~nm}$ and emission at $452 \mathrm{~nm}$ ).

The amount of $\mathrm{NH}_{3}$ formed from the aliphatic amino acid amides was determined using an assay kit for ammonia (Kyowa, Tokyo, Japan). One unit of enzyme activity was defined as the amount of enzyme that liberated $1 \mu \mathrm{mol}$ of D-amino acids from the D-amino acid amides and esters per minute at $55^{\circ} \mathrm{C}$.

\subsection{Enantiomer selectivity assay}

The enantiomers of the amino acids were clearly separated from each other after being derivatized with OPA and NAC, as described above. The mobile phase consisted of $50 \mathrm{mM}$ sodium acetate $(\mathrm{pH} 6.8)$ and methanol $(90: 10, \mathrm{v} / \mathrm{v})$. If ee $(\%)$ is the enantiomer excess: $[(d-L) /(D+L)] \times 100$, the enantiomeric ratio $E$ was determined as $\ln [1-c(1+$ ee) $] / \ln [1-c(1-\mathrm{ee})]$, where $c$ represents the extent of con- version and $e_{p}$ is the enantiomeric excess of the product fraction [8].

The enantioselectivity of the purified enzyme to the DL-amino acid amides was analyzed by HPLC (Youngin, South Korea). The reaction mixture contained $0.1 \mathrm{M}$ Tris- $\mathrm{HCl}(\mathrm{pH} 8.0), 5.0 \mathrm{mM}$ DL-amino acid amides, and 0.003 units of the enzyme. The reaction mixture was incubated at $55^{\circ} \mathrm{C}$ with shaking, then $100 \mu$ l aliquots were withdrawn and diluted 10-fold with $20 \mathrm{mM} \mathrm{HCl}$ solution. After inactivation of the enzyme, the supernatant of the reaction mixture was subjected to HPLC.

\subsection{Determination of molecular mass}

The native molecular mass of the purified enzyme was determined by gel permeation chromatography. A small amount of the purified enzyme solution $(100 \mu \mathrm{l})$ was applied to a Superdex 200 prep grade column (HR 10/30, Pharmacia) and eluted with $0.1 \mathrm{M}$ Tris- $\mathrm{HCl}(\mathrm{pH} 8.0)$ containing $0.1 \mathrm{M} \mathrm{KCl}$ at a flow rate of $0.7 \mathrm{ml} / \mathrm{min}$. Only a single protein peak was observed and the corresponding fractions contained D-methionine amidase activity. To determine the molecular mass of the D-methionine amidase, the column was calibrated with bovine thyroglobulin $\left(M_{\mathrm{r}}\right.$, $669,000)$, catalase $\left(M_{\mathrm{r}}, 232,000\right)$, aldolase $\left(M_{\mathrm{r}}, 158,000\right)$, bovine serum albumin $\left(M_{\mathrm{r}}, 67,000\right)$, chymotrypsinogen A $\left(M_{\mathrm{r}}, 25,000\right)$, and ribonuclease $\mathrm{A}\left(M_{\mathrm{r}}, 13,700\right)$ as reference proteins (gel filtration calibration kit, Pharmacia). The subunit molecular mass was examined by sodium dodecyl sulfate-polyacrylamide gel electrophoresis (SDS-PAGE) under denaturing conditions, as described by Laemmli [16], using reference proteins (LMW electrophoresis calibration kit, Pharmacia).

\subsection{Determination of amino acid sequence}

The purified enzyme was resolved on SDS-12\% PAGE and electrotransferred to a Trans-Blot membrane (polyvinylidene difluoride membrane, Bio-Rad Laboratories, Herciles, California) using $10 \mathrm{mM}$ CAPS (3-[cyclohexylamino]-1-propanesulfonic acid) buffer ( $\mathrm{pH}$ 11.0) containing $10 \%$ methanol. After staining with $0.1 \%$ Coomassie brilliant blue R-250, the gel was destained with $50 \%$ methanol and the D-methionine amidase band excised and washed with distilled water. The $\mathrm{NH}_{2}$-terminal sequence of the purified enzyme was determined using a Beckman PI-2090 automated amino acid sequencer. A homology search for the $\mathrm{NH}_{2}$-terminal amino acid sequences was performed using the BLAST network service with the GenBank database.

\subsection{Protein determination}

The protein concentrations were determined by the method of Bradford [5], using bovine serum albumin as the standard. 


\subsection{Effect of metal ions and inhibitors}

The enzyme solution was pre-incubated with $1.0 \mathrm{mM}$ concentration of metal ions and various concentrations of enzyme inhibitors for $20 \mathrm{~min}$ in $0.1 \mathrm{M}$ Tris- $\mathrm{HCl}(\mathrm{pH} \mathrm{8.0)}$ ). Twenty microliters of the incubation mixture was withdrawn and the enzyme activity determined as described above. The inhibitor concentrations were as follows: EDTA (1.0, $100 \mathrm{mM})$, 2-mercaptoethanol $(1.0,10.0 \mathrm{mM})$, DTT (1.0, $10.0 \mathrm{mM}$ ), tosylamido-2-phenylethylchloromethyl ketone (TPCK; 0.01, 0.1 mM), and PMSF (0.1, $10.0 \mathrm{mM})$.

\subsection{Determination of kinetic constants, $p H$, temperature optima, and thermostability}

The enzyme activity versus the $\mathrm{pH}$ curves was determined over a $\mathrm{pH}$ range of 5.5-13.0. Bis-Tris, potassium phosphate (KPB), Tris-HCl, glycine- $\mathrm{NaOH}(\mathrm{Gly}-\mathrm{NaOH})$, sodium phosphate- $\mathrm{NaOH}(\mathrm{SPB}-\mathrm{NaOH})$, and $\mathrm{NaOH}-\mathrm{KCl}$ buffers were used for $\mathrm{pH}$ ranges from 5.5 to $6.5,6.5$ to 8.0, 8.0 to $9.0,9.0$ to $10.5,10.5$ to 12.0 , and 12.0 to 13.0 , respectively. The optimum temperature was determined within a range of $40-90^{\circ} \mathrm{C}$. The thermostability was determined after heat treatment of $0.1 \mathrm{ml}$ of the enzyme solution (containing $1 \mathrm{mg}$ protein/ml) for $20 \mathrm{~min}$ at various temperatures between 30 and $100^{\circ} \mathrm{C}$. The apparent $K_{\mathrm{m}}$ values were determined at various concentrations of D-amino acid amides $(0.1-10.0 \mathrm{mM})$, and $k_{\text {cat }}$ and $K_{\mathrm{m}}$ were determined by Lineweaver-Burk plots.

\section{Results}

\subsection{D-Amino acid amidase-producing thermophile}

Previously, the current authors isolated a thermophilic bacterium Bacillus sp. BCS-1, which produced a thermostable D-stereospecific dipeptidase in the initial growth phase [3]. After a further assay of useful D-amino acid specific enzymes, it was found that the isolate exhibited D-amino acid amidase activity in cell-free extracts. In the current study, the isolate BCS-1 was found to grow at temperatures between 30 and $58^{\circ} \mathrm{C}$ and its maximum specific growth rate $(\mu)$ was determined as 0.02 at $45^{\circ} \mathrm{C}$ (data not shown). Above and below this culture temperature range, the relative cell growth rapidly decreased and only reached $30 \%$ of the cell growth at $45^{\circ} \mathrm{C}$. Strain BCS- 1 exhibited a typical sigmoidal growth, as found in Bacillus species, and its D-amino acid amidase activity rapidly increased after the stationary phase (data not shown).

For a more precise classification, a sequence analysis of the 16S rRNA was carried out. The BLAST search results for the partial sequences of the 16S rRNA gene of the isolate revealed that it had $99.7 \%$ similarity with that of $B$. borstelensis, as such, strain BCS-1 was designated as B. borstelensis BCS-1 (data not shown).

\subsection{Purification of $\mathrm{D}$-methionine amidase and determination of $\mathrm{NH}_{2}$-terminal amino acid sequence}

Table 1 summarizes the purification of the enzyme. As shown in Table 1, after centrifugation of cell-free extract, most of the D-methionine amidase activity was retained in the supernatant, thereby indicating that the enzyme is not an integral membrane protein. The D-methionine amidase activity in the crude extracts was about $0.15 \mathrm{U} / \mathrm{mg}$ at $55^{\circ} \mathrm{C}$. After five steps of purification, $1.2 \mathrm{mg}$ of protein was obtained with a 207 -fold increase in the specific activity. The apparent molecular mass of the native D-methionine amidase was determined to be about $199 \mathrm{kDa}$ by gel permeation chromatography, while SDS-PAGE revealed only one subunit with an apparent molecular mass of $30 \mathrm{kDa}$ (Fig. 1), suggesting that the native enzyme has a hexameric structure. The $\mathrm{NH}_{2}$-terminal amino acid sequence of the purified $30 \mathrm{kDa}$ subunit enzyme was determined to be MKLFLQVDMEGIQGIVDTQY by automated Edman degradation and was compared with the $\mathrm{NH}_{2}$-terminal amino acid sequences of other amidases and related proteins. From a BLAST search of the protein sequence database (GenBank, EMBL, DDBJ), it was found that the D-methionine amidase did not have any apparent homology with other reported amidases (Table 2). In contrast, the verified sequences of twenty amino acids exhibited a high homology (65\% identity and $85 \%$ similarity) with the sequences of the dppA protein of Bacillus methanolicus [9], and a very similar homology to the dciAA protein, a component of the dipeptide ATP-binding cassette transporter in Bacillus subtilis [17].

Table 1

Purification of D-methionine amidase from $B$. borstelensis $\mathrm{BCS}-\mathrm{1}^{\mathrm{a}}$

\begin{tabular}{|c|c|c|c|c|c|}
\hline Step & Total protein (mg) & Total activity (U) & Specific activity (U/mg) & Fold & Yield $(\%)$ \\
\hline Cell-free extract & 10,240 & 1536 & 0.15 & 1 & 100 \\
\hline Ammonium sulfate & 4640 & 928 & 0.20 & 1.3 & 60 \\
\hline Resource Q & 23 & 129 & 5.60 & 37 & 8 \\
\hline Phenyl Superose & 4.8 & 93 & 19.4 & 129 & 6 \\
\hline Mono Q & 2.7 & 60 & 22 & 147 & 4 \\
\hline Mono S & 1.2 & 37 & 31 & 207 & 2 \\
\hline
\end{tabular}

${ }^{\text {a }} \mathrm{D}$-Methionine amidase activity was determined at $55^{\circ} \mathrm{C}$ with $\mathrm{D}$-alaninamide as the substrate as described in Section 2. 


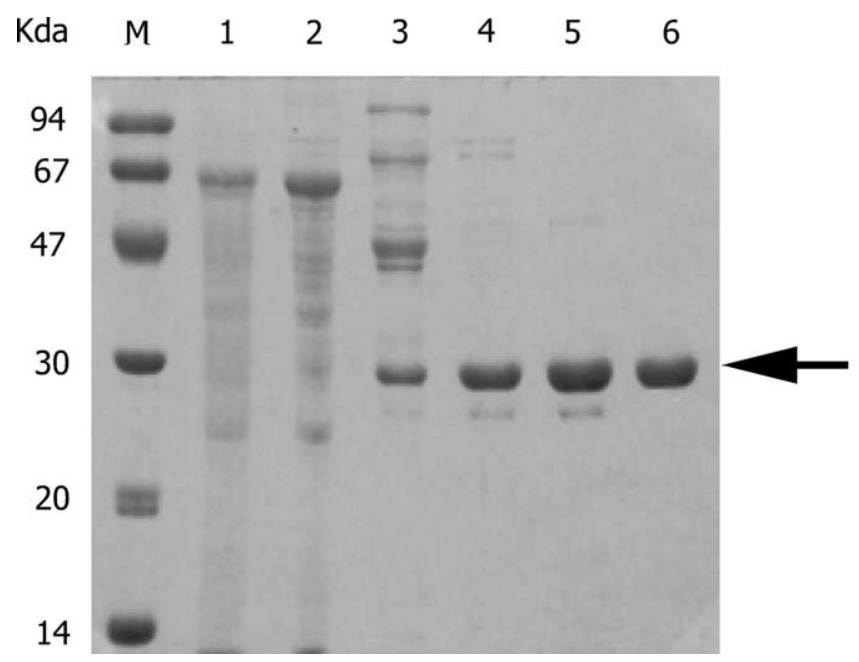

Fig. 1. SDS-PAGE of D-methionine amidase at various stages of purification. Molecular weight marker (M), cell-free extract (lane 1), ammonium sulfate precipitation (lane 2), ion-exchange (Resource Q) chromatography (lane 3), hydrophobic interaction (Phenyl Superose) chromatography (lane 4), ion-exchange (Mono Q) chromatography (lane 5), and ion-exchange (Mono S) chromatography (lane 6). Arrow indicates the purified D-methionine amidase.

Table 2

Comparison of $\mathrm{NH}_{2}$-terminal amino acid sequences of D-methionine amidase from $B$. borstelensis BCS-1 with those of other amidases ${ }^{\mathrm{a}}$ and related proteins $^{\mathrm{b}}$

\begin{tabular}{|c|c|}
\hline Source & equence \\
\hline B. borstelensis BCS-1 & MU FLQVIMES I Q IVETQY \\
\hline DppA of B. methanolicus ${ }^{\mathrm{b}}$ & MKYYISWOMESTTGLIVHTQ \\
\hline DciAA of $B$. subtilis $^{\mathrm{b}}$ & MUTYMSVTME \\
\hline O. anthropi $\mathrm{SV}^{\mathrm{a}}$ & MSDLNNAIQGILDDHVARGV \\
\hline R. erythropolis MP50 & $\mathrm{QE}$ \\
\hline P. chlororaphis B23 & AIIRPTLDAVLDIRTQLHM \\
\hline $\begin{array}{l}\text { Rhodococcus sp. strain } \\
\quad \text { N774 }\end{array}$ & ATIRPDDKAIDAAARHYGI \\
\hline $\begin{array}{l}\text { Brevibacterium sp. strain } \\
\quad \mathrm{R} 312^{\mathrm{C}}\end{array}$ & ATIRPDDKAIDAAARHYGI \\
\hline $\begin{array}{l}\text { Brevibacterium sp. strain } \\
\quad \mathrm{R} 312^{\mathrm{d}}\end{array}$ & MRHGDISSSNDTVGVAVVNY \\
\hline P. aeruginosa $\mathrm{PAC} 433$ & MRHGDISSSNDTVGVAVVNY \\
\hline$R$. rhodochrous $\mathrm{J} 1$ & SSLTPPNSNQMSALNNHFR \\
\hline Rhodococcus sp. & GLHELTLAQVAAKIENKEL \\
\hline \multicolumn{2}{|c|}{$\begin{array}{l}{ }^{\mathrm{a}} \text { The } \mathrm{NH}_{2} \text {-terminal amino acid sequences for the amidases from } \\
\text { O. anthropi } \mathrm{SV} 3 \text { (D-stereospecific amino acid amidase), R. rhodochrous } \\
\mathrm{J} 1 \text {, Rhodococcus sp., Brevibacterium sp. strain } \mathrm{R} 312 \text { (enantioselective } \\
\text { amidase), Brevibacterium sp. strain } \mathrm{R} 312 \text { (wide-spectrum amidase), P. } \\
\text { aeruginosa PAC433, and P. chlororaphis } \mathrm{B} 23 \text { were taken from the se- } \\
\text { quences published by Komeda and Asano [15], Kobayashi et al. [14], } \\
\text { Mayaux and coworkers [18,19], Soubrier et al. [27], Brammar et al. [6], } \\
\text { Mathiopoulos et al. [17], and Nishiyama et al. [20]. } \\
{ }^{\mathrm{b}} \text { dppA was the dipeptide transport protein of Bacillus methanolicus[9], } \\
\text { while dciAA was the gene product of the regulator of the dipeptide } \\
\text { transport operon (dciAA) [26] of } B \text {. subtilis. The highly homologous } \\
\text { regions are shaded. } \\
\text { c The amidase from this species is enantioselective. } \\
{ }^{\mathrm{d}} \text { The amidase from this species has a wide spectrum. }\end{array}$} \\
\hline
\end{tabular}

\subsection{Effects of temperature and $\mathrm{pH}$ on activity, and thermal stability of enzyme}

The optimal reaction temperature for the enzyme was determined to be $70{ }^{\circ} \mathrm{C}$, and about 50 and $70 \%$ of its maximal activity was exhibited at 40 and $85^{\circ} \mathrm{C}$, respectively (Fig. 2A). The enzyme activity with D-alaninamide was restricted to a $\mathrm{pH}$ range of 5.5-13.0 based on the use of BisTris, KPB, Tris- $\mathrm{HCl}$, Gly-NaOH, SPB-NaOH, and $\mathrm{NaOH}-$ $\mathrm{KCl}$ buffers, while its maximum activity was exhibited at $\mathrm{pH}$ 9.5. More than $20 \%$ of its maximal activity was inhibited at $\mathrm{pH} 8.0$, whereas about 80 and $30 \%$ of its maximal activity was exhibited at $\mathrm{pH} 7.0$ and 11.0, respectively (Fig. 2C). It was also found that the enzyme was either inactive or less active below pH 5.5 or above 13.0 (Fig. 2D). Fig. 2B shows the stability of the D-methionine amidase at various temperatures. According to the data in Fig. 2B, no significant loss of the enzyme activity was observed after heat treatment for $20 \mathrm{~min}$ at $65^{\circ} \mathrm{C}$, while about $30 \%$ of the initial activity was lost after heat treatment for $20 \mathrm{~min}$ at $70^{\circ} \mathrm{C}$. However, further heat treatment of the enzyme above $80^{\circ} \mathrm{C}$ caused a rapid decrease in the enzyme activity. Therefore, the above results indicate that the D-methionine amidase of strain BCS-1 is an alkalophilic and thermostable enzyme.

\subsection{Inhibition of enzyme activity}

The inhibitory effects of various compounds on the enzyme activity were investigated (Table 3 ). $\mathrm{Hg}^{2+}$ was

Table 3

Effect of metal ions and various chemicals on enzyme activity

\begin{tabular}{lcc}
\hline Compound added & Concentration $(\mathrm{mM})$ & Relative activity $(\%)^{\mathrm{a}}$ \\
\hline None & & 100 \\
$\mathrm{KCl}$ & 1.0 & 108 \\
$\mathrm{CaCl}_{2}$ & 1.0 & 103 \\
$\mathrm{CoCl}_{2}$ & 1.0 & 463 \\
$\mathrm{HgCl}_{2}$ & 1.0 & 0 \\
$\mathrm{MgCl}_{2}$ & 1.0 & 110 \\
$\mathrm{MnCl}_{2}$ & 1.0 & 123 \\
$\mathrm{ZnCl}_{2}$ & 1.0 & 140 \\
$\mathrm{FeCl}_{3}$ & 1.0 & 92 \\
$2-\mathrm{Mercaptoethanol}$ & 1.0 & 12 \\
& 10.0 & 1.4 \\
$\mathrm{DTT}$ & 1.0 & 3.6 \\
& 10.0 & 1.4 \\
EDTA & 1.0 & 96 \\
& 100 & 10 \\
Chymostatin & 0.01 & 100 \\
& 0.1 & 100 \\
TPCK & 0.01 & 100 \\
& 0.1 & 100 \\
PMSF & 0.1 & 100 \\
& 10.0 & 99
\end{tabular}

Abbreviations: DTT, dithiothreitol; EDTA, ethylenediaminetetraacetic acid; TPCK, tosylamido-2-phenylethylchloromethyl ketone; PMSF, phenylmethanesulphonyl fluoride.

a Activity after $1 \mathrm{~h}$ of incubation in the presence of an effector was determined as described in Section 2. The activity without an effector was $100 \%$. 

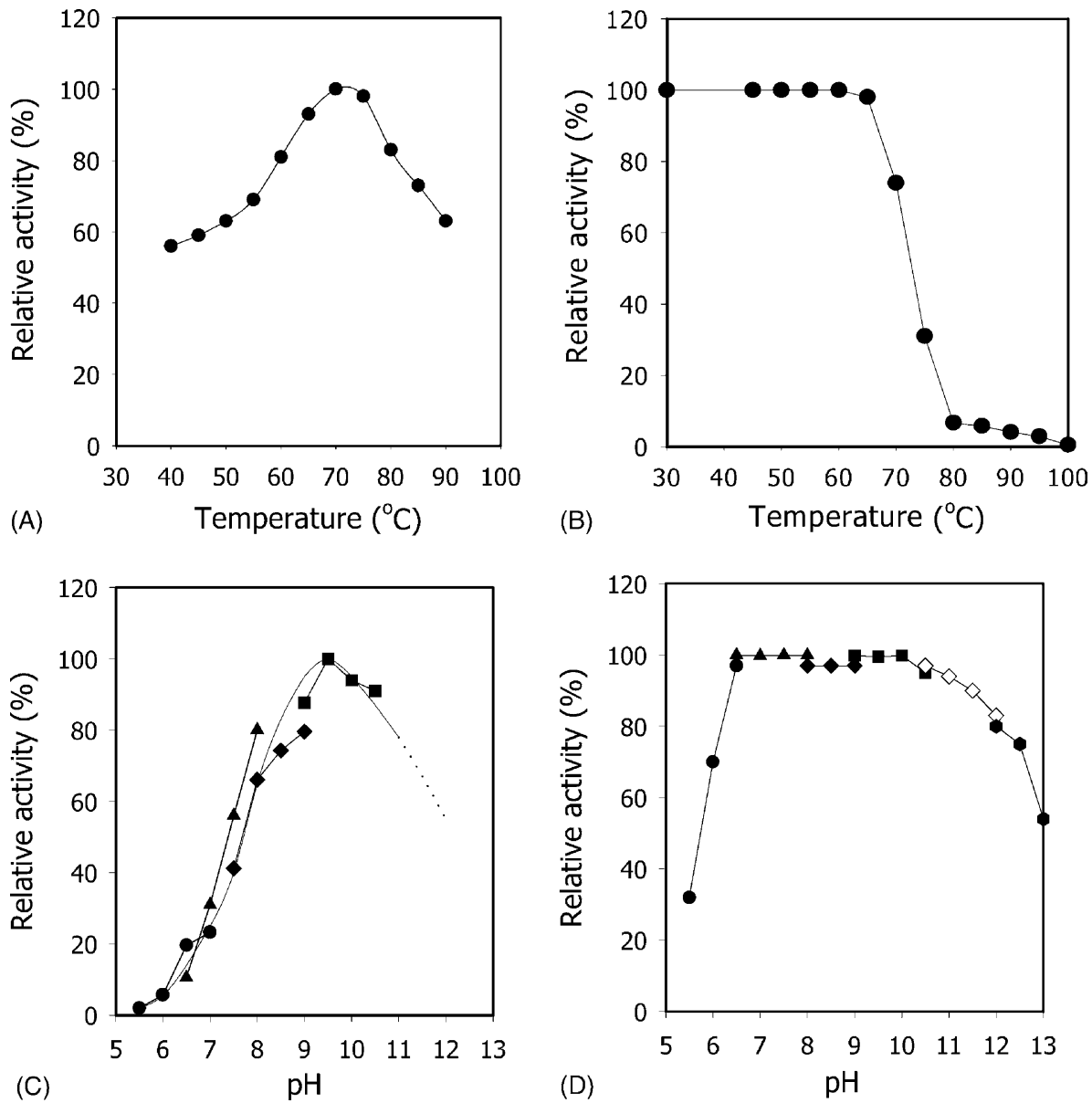

Fig. 2. Effects of temperature and $\mathrm{pH}$ on D-methionine amidase activity of B. borstelensis BCS-1. Optimum temperature (A), thermostability (B), optimum $\mathrm{pH}(\mathrm{C})$, and pH stability (D). Symbols: $(\bullet)$, Bis-Tris; $(\boldsymbol{\Delta}), \mathrm{KPB} ;(\diamond)$, Tris-HCl; $(\boldsymbol{\square}), \mathrm{Gly}-\mathrm{NaOH} ;(\diamond), \mathrm{SPB}-\mathrm{NaOH} ;(\boldsymbol{\bullet}), \mathrm{NaOH}-\mathrm{KCl}$ buffer. The values are shown as relative activity. The maximum relative activity is indicated as $100 \%$. Each experiment was performed in duplicate.

found to completely inhibit the enzyme activity, whereas $\mathrm{Fe}^{3+}$ only partially inhibited the enzyme activity. EDTA also inhibited the enzyme activity, yet $\mathrm{Co}^{2+}$ restored and strongly increased the enzyme activity about fivefold. Sulfhydryl-reducing agents, such as DTT and 2mercaptoethanol, strongly inhibited the enzyme activity. As regards the effects of serine protease inhibitors, chymostatin, PMSF, and TPCK had no effect on the enzyme activity.

\subsection{Substrate specificities and kinetic properties}

Among the various substrates, the purified D-methionine amidase was active toward D-amino acid amides, esters, and arylamides (Table 4). The relative enzyme activities toward representative D-amino acids were as follows: D-methioninamide $(100 \%)$, D-lysinamide $(60 \%)$, D-phenylalaninamide (11\%), D-leucine-p-nitroanilide $(40 \%)$, Dleucine- $\beta$-naphthylamide (69\%), and D-alanine benzyl ester $(22 \%)$. As shown in this table, the D-methionine amidase did not catalyze the hydrolysis of $\mathrm{N}$-acetyl-D-amino acids and di- or tripeptides containing D-amino acid. $\mathrm{NH}_{2}$-terminal protected Z-D-alaninamide was found to be an inactive enzyme substrate, plus L-amino acid-containing dipeptide, tripeptide, and tetrapeptide were also determined to be inert enzyme substrates. Furthermore, L-amino acid amides, such as L-alaninamide, L-aspartamide, L-phenylalaninamide, and various aliphatic amino acid amides containing acetamide, $n$-butylamide, propionamide, and benzamide, were also all determined as inert substrates.

The stereoselectivity of the D-methionine amidase was examined by studying the production of D-phenylalanine from DL-phenylalaninamide (Fig. 3). The enzyme produced D-phenylalanine with an optical purity, and the ee $e_{p}$ (enantiomeric excess of the product; $[(\mathrm{D}-\mathrm{L}) /(\mathrm{D}+\mathrm{L})] \times 100)$ and $E$ (enantiomeric ratio; $\left.\left(k_{\text {cat }} / K_{\mathrm{m}}\right)_{\mathrm{D}} /\left(k_{\mathrm{cat}} / K_{\mathrm{m}}\right)_{\mathrm{L}}\right)$ were 97.1 and $196 \%$, respectively. The $k_{\mathrm{cat}}\left(\mathrm{s}^{-1}\right)$ and $K_{\mathrm{m}}\left(\mathrm{mM}^{-1}\right)$ for the D-methioninamide and D-alaninamide were determined to be $8704,2.82$ and $159,7.4$, respectively. It was also determined that the catalytic efficiencies $\left(k_{\mathrm{cat}} / K_{\mathrm{m}}, \mathrm{mM}^{-1} \mathrm{~s}^{-1}\right)$ of the enzyme for $\mathrm{D}$-methioninamide and $\mathrm{D}$-alaninamide were $3086\left(\mathrm{mM}^{-1} \mathrm{~s}^{-1}\right)$ and $21.5\left(\mathrm{mM}^{-1} \mathrm{~s}^{-1}\right)$, respectively. 
Table 4

Substrate specificity of D-methionine amidase from B. borstelensis BCS-1

\begin{tabular}{|c|c|}
\hline Substrate $^{\mathrm{a}}$ & Relative activity $(\%)$ \\
\hline D-Methioninamide & 100 \\
\hline D-Norvalinamide & 78 \\
\hline D-Norleucinamide & 77 \\
\hline D-Lysinamide & 60 \\
\hline D-Leucinamide & 59 \\
\hline D-Phenylalaninamide & 11.3 \\
\hline D-Tyrosinamide & 10 \\
\hline D-Alaninamide & 9.5 \\
\hline D-Valinamide & 8.7 \\
\hline D-Tryptophanamide & 7 \\
\hline D-Phenylglycinamide & 7 \\
\hline D-Asparaginamide & 4.8 \\
\hline D-Prolinamide & 2.8 \\
\hline D-Glutaminamide & 2.1 \\
\hline D-Aspartamide & 0.3 \\
\hline Z-D-Alaninamide ${ }^{\mathrm{b}}$ & $-^{\mathrm{c}}$ \\
\hline D-Leucine- $p$-nitroanilide & 40.3 \\
\hline D-Phenylalanine- $p$-nitroanilide & 5.4 \\
\hline D-Valine- $p$-nitroanilide & 0.05 \\
\hline D-Alanine- $\beta$-naphthylamide & 33.5 \\
\hline D-Leucine- $\beta$-naphthylamide & 68.5 \\
\hline D-Alanine phenyl ester & 1.7 \\
\hline D-Alanine methyl ester & 25 \\
\hline D-Alanine benzyl ester & 22 \\
\hline D-Valine methyl ester & 14.5 \\
\hline$N$-Acetyl-D-phenylalanine & $-{ }^{c}$ \\
\hline$N$-Acetyl-D-leucine & $-{ }^{c}$ \\
\hline$N$-Acetyl-D-methionine & $-^{c}$ \\
\hline D-Alanyl-D-alanine & $-^{c}$ \\
\hline D-Alanyl-D-alanyl-D-alanine & $-c$ \\
\hline
\end{tabular}

The activity for D-methioninamide, corresponding to $131.4 \mathrm{U} / \mathrm{mg}$, was taken as $100 \%$.

${ }^{\text {a }}$ Each substrate was tested at a concentration of $5.0 \mathrm{mM}$ at $55^{\circ} \mathrm{C}$.

${ }^{\mathrm{b}}$ Benzyloxycarbonyl.

c Negative reaction.

\section{Discussion}

The current study described the purification and characterization of a new thermostable D-methionine amidase from B. borstelensis BCS-1 isolated from Korean soil. This is the first report on the production of a thermostable D-amino acid amidase from a thermophile. The purified enzyme exhibited new substrate specificities and enzyme characteristics when compared to other previously reported D-amino acid amidases and showed no protein similarity with any other D-amino acid-specific enzymes discovered from different microorganisms. The purified D-methionine amidase from BCS-1 exhibited strong amidase activity toward D-amino acid amides (D-norvalinamide, D-lysinamide, D-leucinamide, D-phenylalaninamide, D-tyrosinamide, D-alaninamide, and D-asparaginamide), esters (D-alanine phenyl ester, D-alanine methyl ester, D-alanine benzyl ester, and D-valine methyl ester), and arylamides (D-alanine- $\beta$-naphthylamide, Dleucine- $\beta$-naphthylamide, and D-leucine- $p$-nitroanilide) and showed a high stereospecificity to D-amino acids. Among
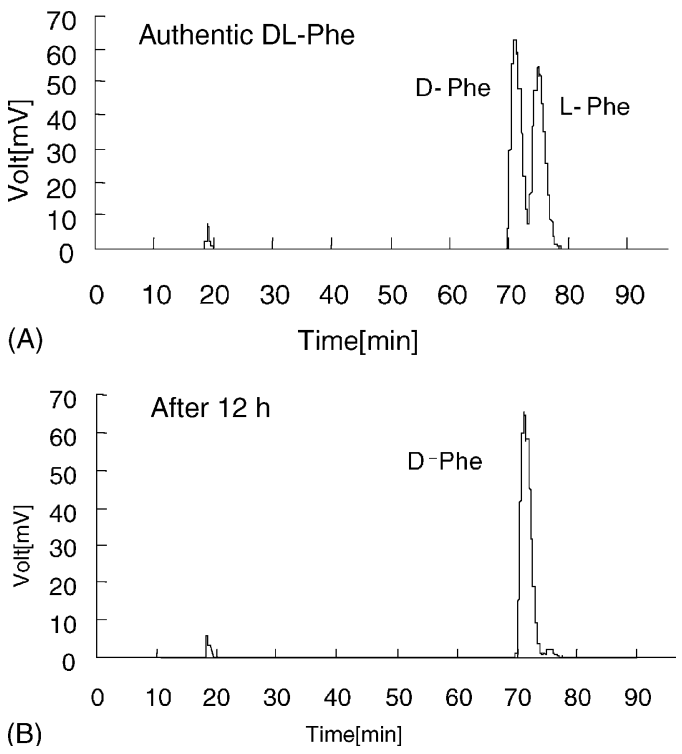

Fig. 3. HPLC analysis of production of D-phenylalanine from DL-phenylalaninamide by new thermostable D-methionine amidase. The quantitative determination of DL-phenylalanine was confirmed by means of $50 \mathrm{mM}$ sodium acetate buffer ( $\mathrm{pH}$ 6.8): $\mathrm{MeOH}$ linear gradient HPLC system after being derivatized with $o$-phthaldialdehyde (OPA) together with $\mathrm{N}$-acetyl-L-cysteine (NAC). The amount of generated DL-phenylalanine (B) was estimated after reacting for $12 \mathrm{~h}$ at $50^{\circ} \mathrm{C}$ in comparison with authentic DL-phenylalanine (A).

the substrates tested, D-methioninamide was the most readily hydrolyzed, whereas the other D-amino acid-containing dipeptides, oligopeptides, and acyl compounds and L-amino acid-containing amides, peptides, and arylamides were all determined to be inactive substrates.

As regards other research on D-amino acid amide-specific enzymes, Ozaki et al. [21] reported on the purification and application of a D-alaninamide-specific amide hydrolase (Damidase) from Arthrobacter sp. NJ-26 to produce D-alanine from DL-alaninamide. This enzyme was produced in the presence of DL-alaninamide as an inducer, its molecular mass is estimated to be about $67 \mathrm{kDa}$ by gel permeation chromatography, and its subunit structure is composed of a monomeric polypeptide. The enzyme exhibits D-amidase activity in both D-alaninamide and L-alaninamide, shows a maximal enzyme activity at $45^{\circ} \mathrm{C}$, and exhibits no amidase activity toward DL-leucinamide, DL-phenylalaninamide, and DL-tryptophanamide. Another D-stereospecific amino acid amidase from Ochrobactrum anthropi SV3 was cloned and characterized [15]. This enzyme is composed of 363 amino acid residues (molecular mass $40 \mathrm{kDa}$ ), and its sequence shows a homology to the alkaline D-peptidase from Bacillus cereus DF4-B (32\% identity), DD-peptidase from Streptomyces R61 (29\% identity), and other penicillin-recognizing proteins. This enzyme is active toward D-phenylalaninamide, D-tryptophanamide, D-methioninamide, and D-alaninamide, yet D-lysinamide, $\mathrm{D}$-asparaginamide have been determined as inactive substrates. 
The stability of the D-methionine amidase from $B$. borstelensis $\mathrm{BCS}-1$ as regards $\mathrm{pH}$ and temperature was found to be very different from those of other amidases. As shown in Fig. 2, the D-methionine amidase from B. borstelensis BCS-1 exhibited its maximal activity at $70^{\circ} \mathrm{C}$ and $\mathrm{pH} 9.5$, whereas the D-stereospecific amino acid amidase from $O$. anthropi exhibits its maximal activity at $45^{\circ} \mathrm{C}$ within a $\mathrm{pH}$ range of 8.5-9.0 [15] and the D-alaninamide-specific amide hydrolase (D-amino acid amidase) of Arthrobacter sp. NJ-26 exhibits its maximal activity at $44^{\circ} \mathrm{C}$ and $\mathrm{pH} 7.5$ [21].

The analysis of the $16 \mathrm{~S}$ rRNA gene sequence revealed that strain BCS-1 had $99.7 \%$ homology with B. borstelensis [25]. However, the culture characteristics of strain BCS-1 showed a slight difference compared to those of B. borstelensis, as specified above. As regards the specific growth rates $(\mu)$, strain $B$. borstelensis BCS-1 and $B$. borstelensis ATCC 51667 (type strain is NRS 1029b) both exhibited their maximum at $45^{\circ} \mathrm{C}$, although the maximal growth temperatures for the two strains were different. Strain BCS-1 exhibited its optimum and maximum cell growth at 45 and $58{ }^{\circ} \mathrm{C}$, respectively, yet $B$. borstelensis ATCC 51667 (NRRL NRS948) [20] exhibits its optimum and maximum cell growth at 45 and $50{ }^{\circ} \mathrm{C}$, respectively.

The studies on the effects of metal ions and enzyme inhibitors on the D-methionine amidase activity revealed that the enzyme was specifically influenced by metal ions. The addition of $\mathrm{Co}^{2+}$ in the reaction mixture strongly reactivated and increased the enzyme activity more than five-fold, and the addition of $\mathrm{Zn}^{2+}$ also increased the enzyme activity 1.4-fold, whereas $\mathrm{Fe}^{3+}$ partially inhibited the enzyme activity. Serine protease inhibitors, such as chymostatin, PMSF, and TPCK, did not produce any inhibitory effects, yet an inhibition of more than $90 \%$ was detected in $0.1 \mathrm{M}$ EDTA. When sulfhydryl-reducing agents, such as DTT and 2-mercaptoethanol, were added to the enzyme solution, about 99 or $96 \%$ of the D-methionine amidase activity was inhibited implying the disulfide bonds in the protein may be essential for the enzyme structure. According to previous reports, D-alaninamide-specific amide hydrolase [21] is inhibited by the addition of $10 \mathrm{mM}$ concentration of $\mathrm{Zn}^{2+}$, $\mathrm{Co}^{2+}$, and $\mathrm{Mn}^{2+}$, while $\mathrm{D}$-stereospecific amino acid amidase [2] is completely inhibited in the presence of PMSF, $\mathrm{Co}^{2+}$, and $\mathrm{Zn}^{2+}$. However, in the case of the D-methionine amidase from strain BCS-1, PMSF, $\mathrm{Co}^{2+}$, and $\mathrm{Zn}^{2+}$ had no inhibitory effect on the enzyme activity. Accordingly, from these results, it would appear that the D-methionine amidase of $B$. borstelensis BCS-1 is a new thermostable metalloenzyme, and the inhibition of the enzyme activity was seemingly due to the breakdown of disulfide bonds in the protein molecule and changes in the structural conformation by the action of sulfhydryl-reducing agents.

The kinetic parameters of the D-methionine amidase on $D$-amino acid amide revealed that the catalytic efficiency $\left(k_{\text {cat }} / K_{\mathrm{m}}\right)$ of the D-methioninamide and D-alaninamide were $3086\left(\mathrm{mM}^{-1} \mathrm{~s}^{-1}\right)$ and $21.5\left(\mathrm{mM}^{-1} \mathrm{~s}^{-1}\right)$ at $55^{\circ} \mathrm{C}$, respectively. Based on the enantiomeric excess measurement using kinetic resolution, the D-methionine amidase showed D-enantiomer selectivity to DL-phenylalaninamide (ee = $97.1 \%, E=196$ ), therefore, the enzyme can be applied to the production of D-phenylalanine via the chiral resolution of DL-phenylalaninamide and other D-amino acids from DL-amino acid amides. These results were further verified from the enantioselective synthesis of D-phenylalanine from DL-phenylalaninamide based on the enzymatic conversion of $\mathrm{D}$-methionine amidase, although the reaction was not carried out under optimized conditions. In this experiment, only D-phenylalanine was generated from DLphenylalaninamide, while L-phenylalaninamide remained in the reaction mixture (Fig. 3B).

The $\mathrm{NH}_{2}$-teminal amino acid sequences (20 residues) of the D-methionine amidase did not exhibit any sequence similarity with any other previously reported amidases, yet did show $65 \%$ identity and $85 \%$ similarity with the dppA and dciAA from Bacillus strains, in which the genes are known as ABC transporters [17]. dciAA is gene product of dciA operon and sequence analysis showed that its putative products are homologous to bacterial peptide transport systems. Furthermore, this gene transcript expressed early during sporulation, and induced by nutrient depletion or spore inducing agent (decoyinine). As a result, we propose that thermostable D-stereospecific dipeptidase and D-methionine amidase of $B$. borstelensis BCS-1 are closely related to production of D-amino acid and peptide transport for spore formation though their physiological roles were not identified yet. Accordingly, this is the first time, a protein with a homology to an $\mathrm{ABC}$ transporter has been identified and its enzymatic characteristics reported.

\section{Acknowledgments}

This work was supported by National Research Laboratory (NRL) program Grant NLM0020123 from the Ministry of Science and Technology of Korea.

\section{References}

[1] Asano Y, Nakazawa A, Kato Y, Kondo K. Properties of a novel Dstereospecific aminopeptidase from Ochrobactrum anthropi. J Biol Chem 1989;264:14233-9.

[2] Asano Y, Mori T, Hanamoto S, Kato Y, Nakazawa A. A new D-stereospecific amino acid amidase from Ochrobactrum anthropi. Biochem Biophys Res Commun 1989;162:470-4.

[3] Baek DH, Kwon SJ, Park JS, Lee S-G, Mheen TI, Sung M-H. Discovery of D-stereospecific dipeptidase from thermophilic Bacillus sp. BCS-1 and its application for synthesis of D-amino acidcontaining peptide. J Microbiol Biotechnol 1999;9:646-9.

[4] Bajusz S, Kovacs M, Gazdag M, Bokser L, Karashima T, Csernus VJ, et al. Highly potent antagonists of luteinizing hormone-releasing hormone free of edematogenic effects. Proc Natl Acad Sci USA 1988;85:1637-41.

[5] Bradford MM. A rapid and sensitive method for the quantitation of microgram quantities of protein utilizing the principle of protein dye binding. Anal Biochem 1976;72:248-54. 
[6] Brammar WJ, Charles IG, Matfield M, Cheng-Pin L, Drew RE, Clarke PH. The nucleotide sequence of the amiE gene of Pseudomonas aeruginosa. FEBS Lett 1987;215:291-4.

[7] Cheggour A, Fanuel L, Joris B, Bouillenne F, Devreese B, Driessche $\mathrm{GV}$, et al. The dppA gene of Bacillus subtilis encodes a new Daminopeptidase. Mol Microbiol 2000;38:504-13.

[8] Chen CS, Fujimoto Y, Girdaukas G, Sih CJ. Quantitative analysis of biochemical kinetic resolutions of enantiomers. J Am Chem Soc 1982;104:7294-9.

[9] Cue D, Lam H, Dillingham RL, Hanson RS, Flickinger MC. Genetic manipulation of Bacillus methanolicus, a gram-positive thermotolerant methylotroph. Appl Environ Microbiol 1997;63:140620.

[10] Fisher GH, Aniello AD, Vetere A, Padula L, Cusano GP, Man EH. Free D-aspartate in normal and Alzheimer brain. Brain Res Bull 1991;26:983-5.

[11] Friedman M. Chemistry, nutrition, and microbiology of D-amino acids. J Agric Food Chem 1999;47:3457-79.

[12] Gill I, Jorba LFRX, Vulfson EN. Biologically active peptides and enzymatic approaches to their production. Enzyme Microb Technol 1996; 18:162-83

[13] Janusz JM, Gardlik JM, Young PA, Burkes RV, Stoll SJ, Estelle AF, et al. High potency dipeptide sweeteners. 1. L-Asp-D-phenylglycine esters. J Med Chem 1990;33:1052-61.

[14] Kobayashi M, Komeda H, Nagasawa T, Nishiyama M, Horinouchi $\mathrm{S}$, Beppu $\mathrm{T}$, et al. Amidase coupled with low-molecular mass nitrile hydratase from Rhodococcus rhodochrous J1. Eur J Biochem 1993;217:327-36.

[15] Komeda H, Asano Y. Gene cloning, nucleotide sequencing, and purification and characterization of the D-stereospecific aminoacid amidase from Ochrobactrum anthropi SV3. Eur J Biochem 2000;267:2028-35.

[16] Laemmli UK. Cleavage of structural proteins during the assembly of the head of bacteriophage T4. Nature (London) 1970;227:680-5

[17] Mathiopoulos C, Mueller JP, Slack FJ, Murphy CG, Patankar S, Bukusoglu G, et al. A Bacillus subtilis dipeptide transport system expressed early during sporulation. Mol Microbiol 1991;5:1903-13.

[18] Mayaux JF, Cerbelaud E, Soubrier F, Faucher D, Pétré D. Purification, cloning, and primary structure of an enantiomer-selective amidase from Brevibacteriumsp. strain R312: structural evidence for genetic coupling with nitrile hydratase. J Bacteriol 1990;172:6764-73.

[19] Mayaux JF, Cerbelaud E, Soubrier F, Yeh P, Balanche F, Pétré D. Purification, cloning, and primary structure of a new enantiomerselective amidase from a Rhodococcus strain: structural evidence for a conserved genetic coupling with nitrile hydratase. J Bacteriol 1991;173:6694-704.

[20] Nishiyama M, Horinouchi S, Kobayashi M, Nagasawa T, Yamada $\mathrm{H}$, Beppu T. Cloning and characterization of genes responsible for metabolism of nitrile compounds from Pseudomonas chlororaphis B23. J Bacteriol 1991;173:2465-72.

[21] Ozaki A, Kawasaki K, Yagasaki M, Hashimoto Y. Enzymatic production of D-alanine from DL-alaninamide by novel Dalaninamide-specific amide hydrolase. Biosci Biotech Biochem 1992;56:1980-4.

[22] Pert CB, Pert A, Chang JK, Fong BTW. D-Ala ${ }^{2}$-met-enkephalineamide: a potent, long-lasting synthetic pentapeptide analgesic. Science 1976;194:330-2.

[23] Rhobinson T. D-Amino acids in higher plants. Life Sci 1976;19:1097102.

[24] Schleifer KH, Kandler O. Peptidoglycan types of bacterial cell walls and their taxonomical implications. Bacteriol Rev 1972;36:407-77.

[25] Shida O, Takagi H, Kadowaki K, Udaka S, Nakamura LK, Komagata K. Proposal of Bacillus reuszeri sp. nov., Bacillus formosus sp. nov., nom. rev., and Bacillus borstelensis sp. nov., nom. rev. Int J Syst Bacteriol 1995;45:93-100.

[26] Slack FJ, Mueller JP, Strauch MA, Mathiopoulos C, Sonenshein AL. Transcriptional regulation of a Bacillus subtilis dipeptide transport operon. Mol Microbiol 1991;5:1915-25.

[27] Soubrier F, Lévy-Schil S, Mayaux JF, Pétré D, Arnaud A, Crouzet J. Cloning and primary structure of the wide-spectrum amidase from Brevibacterium sp. 312: high homology to the amiE product from Pseudomonas aeruginosa. Gene 1992;116:99-104.

[28] Sugie M, Suzuki H, Tomizuka N. Purification and properties of a peptidase from Norcardia orientalis specific to D-amino acid peptides. Agric Biol Chem 1986;50:1397-402.

[29] Wu Z, Wright GD, Walsh CT. Overexpression, purification, and characterization of Van X, a D,D-dipeptidase which is essential for vancomycin resistance in Enterococcus faecium BM4147. Biochemistry 1995;34:2455-63.

[30] Yagasaki M, Ozaki A. Industrial biotransformations for the production of D-amino acids. J Mol Catal B Enzymatic 1998;4:1-11.

[31] Yoon JH, Lee ST, Park YH. Inter-and intraspecific phylogenetic analysis of the genus Nocardioides and related taxa based on $16 \mathrm{~S}$ rDNA sequence. Int J Syst Bacteriol 1988;48:187-94.

[32] Yoshida YK, Kobayashi M, Yasuda A, Fujita T, Minakata H, Nomoto K, et al. A novel D-amino acid-containing peptide, fulyal, coexists with fulicin gene-related peptides in Achatina atria. Peptides 1997; 18:347-54. 